\title{
Subunit Composition of Nicotinic Acetylcholine Receptors from Chick Ciliary Ganglia
}

\author{
Stanley W. Halvorsen and Darwin K. Berg \\ Department of Biology, University of California, San Diego, La Jolla, California 92093
}

\begin{abstract}
Nicotinic ACh receptors were immunoaffinity-purified from chick ciliary ganglia, radioiodinated, and examined by SDSPAGE. Components with $M_{r}$ 's of 49,52 , and $60 \mathrm{kDa}$ were obtained. Limited proteolysis produced different peptide maps from the components, confirming the 3 as distinct species. All are glycoproteins since treatment with glycopeptidase $F$ altered their migration during electrophoresis. The $60 \mathrm{kDa}$ component appears to be encoded by the AChR $\alpha 3$ gene since it was selectively immunoprecipitated by an antiserum to a fusion protein containing a putative cytoplasmic region of the predicted $\alpha 3$ gene product. The $49 \mathrm{kDa}$ component selectively cross-reacted on immunoblots with 4 monoclonal antibodies that recognize a component of similar size in AChR preparations from chicken brain. The $\mathbf{5 2}$ $\mathrm{kDa}$ component is a novel species not previously identified in preparations of brain AChRs. If all 3 components represent integral AChR subunits, they may compose 2 receptor subtypes in the ganglion, e.g., one containing 49 and $60 \mathrm{kDa}$ subunits and another containing 52 and $60 \mathrm{kDa}$ subunits. This is supported by the finding that a receptor preparation can be obtained containing only the 49 and $60 \mathrm{kDa}$ components and is consistent with reports of brain AChRs having only 2 types of subunits. Alternatively, ganglionic AChRs may contain 3 or more types of subunits, with at least one being selectively lost under certain conditions.
\end{abstract}

Nicotinic acetylcholine receptors (AChRs) are widely distributed throughout the vertebrate nervous system and appear similar to muscle and electric organ AChRs in a number of physiological and pharmacological aspects (for review, see Schuetze and Role, 1987). Recently, however, a combination of molecular approaches has identified differences between neuronal and muscle AChRs. Muscle and electric organ AChRs are pentameric membrane proteins of about $250 \mathrm{kDa}$, composed of 4 types of subunits $\left(\alpha_{2} \beta \gamma \delta\right)$. The $\alpha$ subunit is the smallest of the set and is associated with the agonist binding site on the receptor as indicated by affinity alkylation experiments. Brain AChRs,

\footnotetext{
Received Aug. 7, 1989; revised Oct. 23, 1989; accepted Dec. 4, 1989.

We thank Drs. Ralf Schoepfer, Paul Whiting, and Jon Lindstrom of the Salk Institute for giving us the hybridoma cell line secreting mAb 35 and for generously providing us with the other anti-AChR mAbs and antisera used in the present study. We thank Dr. Asha Khanna (UCSD) for adapting the $\mathrm{MgCl}_{2}$ step for recovering AChR from mAb 35-Sepharose columns. Susan Tsunoda and Dannielle Pellegrin prepared the cell cultures; Christian Elly dissected the ganglia. Grant support was provided by NIH grants RO1 NS12601 and PO1 NS25916 and by grants from the Muscular Dystrophy Association and the American Heart Association with funds contributed in part by the California Heart Association.

Correspondence should be addressed to Darwin K. Berg, Department of Biology, B-022, University of California, San Diego, La Jolla, CA 92093.

Copyright (C) 1990 Society for Neuroscience $0270-6474 / 90 / 061711-08 \$ 02.00 / 0$
}

though similar in size, may contain fewer kinds of subunits, and a large subunit appears to be associated with the agonist binding site. Components of 51 and $79 \mathrm{kDa}$ are obtained when AChRs are purified from rat brain and examined by SDS-PAGE (Whiting and Lindstrom, 1987a). Similar analysis of 2 AChR subtypes purified from chick brain reveals components of 49 and $59 \mathrm{kDa}$, and 49 and $75 \mathrm{kDa}$, respectively (Whiting et al., 1987b). Affinity alkylation of chick and rat brain AChRs with a reagent directed to the agonist binding site preferentially labels the largest species of each pair (Whiting and Lindstrom, 1987b).

Similar conclusions about the structure of neuronal AChRs emerge from gene analysis. Three types of neuronal AChR $\alpha$ genes $(\alpha 2, \alpha 3$, and $\alpha 4)$ in chick and rat have been identified and shown to be highly homologous to the gene encoding the muscle $\alpha$ subunit ( $\alpha$ 1, Boulter et al., 1986; Goldman et al., 1987; Nef et al., 1988; Wada et al., 1988). Three types of neuronal AChR $\beta$ genes $(\beta 2, \beta 3$, and $\beta 4)$ have also been identificd in rat (Dencris et al., 1988, 1989; Duvoisin et al., 1989) and have been so named because 2 of them ( $\beta 2$ and $\beta 4$ ) have been shown capable of substituting for the muscle $\mathrm{AChR} \beta$ gene ( $\beta 1)$ in assembling functional muscle AChRs in oocytes (Deneris et al., 1988; Duvoisin et al., 1989). A gene equivalent to $\beta 2$ has also been identified in chicken (Nef et al., 1988; Schoepfer et al., 1988). Any of the 3 rat neuronal $\alpha$ gene products $(\alpha 2, \alpha 3$, or $\alpha 4)$ in combination with either the rat $\beta 2$ or $\beta 4$ gene product produces functional AChRs in Xenopus oocytes (Boulter et al., 1987; Wada et al., 1988; Duvoisin et al., 1989; Papke et al., 1989). Similar results have been obtained with the chick $\alpha 4$ and $\beta 2$ gene products (Ballivet et al., 1988). Results of other combinations have not yet been reported. Clearly, 2 neuronal $A C h R$ genes are adequate to produce a functional receptor. Either neuronal AChRs differ from muscle AChRs with respect to subunit heterogeneity or additional neuronal $\mathrm{AChR}$ subunits are present but have subtle effects on receptor function.

Chick ciliary ganglion neurons express AChRs that mediate primary synaptic transmission through the ganglion. Of the known neuronal AChR $\alpha$ genes, only $\alpha 3$ is expressed in substantial amounts in the ganglion (Boyd et al., 1988). $\alpha 2$ transcripts are undetectable, and $\alpha 4 \mathrm{mRNA}$ is present in trace amounts at most. The ganglion does have small amounts of $\beta 2$ mRNA (Boyd et al., 1988). Previous studies of ciliary ganglion AChRs identified a subunit of about $59 \mathrm{kDa}$ likely to be associated with the agonist binding site since the subunit was preferentially labeled with a neurotoxin that blocked receptor function (Halvorsen and Berg, 1987). Here, we show that 3 distinct components are obtained by SDS-PAGE of AChRs immunoaffinity purified from chick ciliary ganglia using a monoclonal antibody (mAb 35) previously shown to recognize ganglionic 
AChRs (Jacob et al., 1984; Smith et al., 1985, 1986; Halvorsen and Berg, 1987). The largest component appears to be an $\alpha 3$ gene product and corresponds to the receptor species previously labeled with the neurotoxin. The smallest component is similar in size and antigenicity to a component present in AChR preparations from brain. The component of intermediate size represents a new species not previously identified with neuronal AChRs.

\section{Materials and Methods}

Receptor purification. Chick ciliary ganglia were dissected from 18-19 $\mathrm{d}$ embryos, quick-frozen, and stored at $-70^{\circ} \mathrm{C}$ until used. Routinely, $150-200$ ganglia were homogenized in a ground glass homogenizer on ice in $1 \mathrm{ml}$ of $50 \mathrm{mM} \mathrm{NaPO}_{4}, \mathrm{pH} 7.4$ (buffer), and the protease inhibitors $1 \mathrm{~mm}$ EDTA, $1 \mathrm{~mm}$ EGTA, $1 \mu \mathrm{g} / \mathrm{ml}$ phosphoramidon, $10 \mu \mathrm{g} / \mathrm{ml} \mathrm{leu}$ peptin, $1 \mathrm{~mm}$ PMSF, $80 \mu \mathrm{g} / \mathrm{ml}$ iodoacetamide, and $0.1 \mathrm{~mm}$ pepstatin A. The homogenate was centrifuged at $15,600 \times g$ for $15 \mathrm{~min}$ at $4^{\circ} \mathrm{C}$ and the supernatant discarded. The particulate fraction was resuspended in $0.6 \mathrm{ml}$ buffer and centrifuged as above. Triton $\mathrm{X}-100$ at $1 \%$ was included in this and all subsequent purification steps unless otherwise indicated. The supernatant was recovered and applied to a small DEAEcellulose column $(0.38 \mathrm{ml})$ equilibrated in buffer. After washing the column with $1.2 \mathrm{ml}$ of buffer containing $50 \mathrm{~mm} \mathrm{NaCl}$, the bound material was eluted with $0.5 \mathrm{ml}$ of buffer containing $0.33 \mathrm{M} \mathrm{NaCl}$. The eluate was incubated twice with $50 \mu \mathrm{l}$ of rat $\mathrm{IgG}-$ Sepharose to remove material that absorbed nonspecifically to the matrix and then was divided and incubated either with $2 \mu \mathrm{M}$ mAb 35 as a control to block $\mathrm{AChR}$ binding to $\mathrm{mAb} 35-$ Sepharose subsequently or with nonimmune rat serum (1:10) for $20 \mathrm{~min}$ at room temperature. The fractions were then incubated with $10 \mu \mathrm{l}$ of $\mathrm{mAb} 35-$ Sepharose for $60 \mathrm{~min}$ at room temperature on an orbital shaker to absorb AChRs. (The mAb 35Sepharose had been pretreated with $0.1 \mathrm{ml}$ of $50 \mathrm{~mm}$ sodium citrate, $\mathrm{pH} 3.0$, immediately beforehand to remove material that might otherwise contaminate the $\mathrm{AChR}$ preparation and then was re-equilibrated with buffer.) The procedure absorbed $80-90 \%$ of $A C h R$ to the $\mathrm{mAb} 35-$ Sepharose as determined by ${ }^{125} \mathrm{I}-\mathrm{mAb} 35$ binding (data not shown). In some purifications, samples depleted of AChRs in this manner were reexposed to $\mathrm{mAb} 35-$ Sepharose as a "receptor-free" control for asscssing binding of non-AChR components to the matrix.

Before radioiodinating the absorbed receptor, the AChR-mAb 35Sepharose complex was washed twice with $1 \mathrm{ml}$ aliquots of buffer and then once with $1 \mathrm{ml}$ of $5 \mathrm{~mm} \mathrm{NaPO}_{4}, \mathrm{pH} 7.4$, containing $0.5 \mathrm{M} \mathrm{NaCl}$ and $0.5 \%$ Tween 20 instead of Triton X-100. The washed complex was radioiodinated with carrier-free $\mathrm{Na}^{125} \mathrm{I}$ and Chloramine $\mathrm{T}$, and the reaction was terminated by washing 3 times with $1 \mathrm{ml}$ buffer (with Triton $\mathrm{X}-100$ ). The complex was then rinsed once with $0.5 \mathrm{ml} 5 \mathrm{~mm} \mathrm{NaPO}$, pH 7.4, containing $0.5 \mathrm{M} \mathrm{NaCl}$ and $0.5 \%$ Triton X-100, and the AChRs eluted with 2 sequential exposures to $30 \mu \mathrm{l}$ of $10 \mathrm{~mm}$ sodium citrate, $\mathrm{pH} 3.0$, containing $0.5 \mathrm{M} \mathrm{NaCl}$ and $0.5 \%$ Triton $\mathrm{X}-100$. The eluates were immediately neutralized with $60 \mu \mathrm{l}$ buffer containing $5 \mathrm{mg} / \mathrm{ml}$ $\beta$-lactoglobulin and protease inhibitors. Possible ${ }^{125} \mathrm{I}$-labeled $\mathrm{IgG}$ in the eluate (caused by absorption of IgG to the $\mathrm{mAb} 35-\mathrm{Scpharosc}$ followed by labeling and subsequent elution) was removed with $2 \mathrm{mg}$ Staphylococcus aureus cells precoated with goat anti-rat IgG. An aliquot of the receptor preparation was then diluted in SDS sample buffer $(0.125 \mathrm{M}$ Tris- $\mathrm{HCl}, \mathrm{pH} 6.8,3.5 \% \mathrm{SDS}, 5 \%$ 2-mercaptoethanol, $10 \%$ glycerol) and analyzed by SDS-PAGE with $4 \%$ acrylamide in the stacking gel and $9 \%$ acrylamide in the separation gel as previously described (Laemmli, 1970 Halvorsen and Berg, 1987). Autoradiography of dried gels was carried out using Kodak X-OMAT film with intensifying screens. Molecularweight markers used included phosphorylase B $(97,400)$, human transferrin $(85,000)$, BSA $(68,000)$, pyruvate kinase $(57,000)$ fumarase $(49,000)$, ovalbumin $(43,000)$, and carbonic anhydrase $(29,000)$.

Two methods were used to prepare samples for a second round of affinity purification. In the first method, $\mathrm{AChR}$ was radioiodinated during the first round of immunoabsorption, acid-eluted, neutralized, and treated with Staphylococcus/goat anti-rat IgG all as described above, and then was applied to a fresh aliquot of mAb 35-Sepharose for $1 \mathrm{hr}$ at room temperature. Rinsing and elution in the second round were carried out as described above except that the final eluates were neutralized with $3 \times$ SDS gel sample buffer. Omission of the DEAE-cellulose step in this case did not alter the results. In the second method, ${ }^{125} I-$ AChR was eluted from the first round of immunoabsorption with 1.5 column volumes of $4.5 \mathrm{M} \mathrm{MgCl}_{2}$ (Mains and Eipper, 1976) in $20 \mathrm{~mm}$ Tris- $\mathrm{HCl}, \mathrm{pH} 7.4$, with $0.1 \%$ Tween $20 . \mathrm{MgCl}_{2}$ in the sample was reduced to less than $30 \mathrm{~mm}$ by sequential dilution and concentration with a 2 $\mathrm{ml}$ Centricon-30 unit (Amicon) using $50 \mathrm{~mm}$ Tris- $\mathrm{HCl}$, pH 7.4, containing $0.5 \%$ Triton $\mathrm{X}-100$, protease inhibitors, and $\beta$-lactoglobulin as carrier protein. Contaminating ${ }^{125} \mathrm{I}-\mathrm{IgG}$ was removed with Staphvlococcus/goat anti-rat IgG, and the sample was applied to a fresh aliquot of $\mathrm{mAb} 35-$ Sepharose and treated as described above for the first method.

Peptide mapping. Peptide mapping of subunits after partial enzymatic proteolysis was performed by a modification of the method of Cleveland et al. (1977), where "2s I-AChR subunits were resolved on $9 \%$ polyacrylamide gels as described above and the gels sliced to obtain isolated receptor subunits. The protease Staphylococcus V8 was dissolved in $0.125 \mathrm{~m}$ Tris- $\mathrm{HCl}, \mathrm{pH} 6.8,0.1 \%$ SDS, $5 \%$ glycerol, $1 \mathrm{~mm}$ EDTA. The gel slices of interest $(2,000-10,000 \mathrm{cpm})$ were equilibrated for $30 \mathrm{~min}$ with $20 \mu$ lof the same buffer supplemented with $20 \%$ glycerol. The gel slice and buffer were then applied to a second SDS gel with $15 \%$ acrylamide and were covered with $5 \mu \mathrm{l}$ of $1 \mathrm{mg} / \mathrm{ml}$ Staphylococcus V8. Electrophoresis was carried out at $10 \mathrm{~mA}$ until the dye front was 0.5 $\mathrm{cm}$ from the separation gel. The power was then turned off to allow enzymatic digestion. After $30 \mathrm{~min}$, electrophoresis of the newly generated peptides was resumed, and analysis of the gels performed as described above.

Glycopeptidase F digestion. ${ }^{125} \mathrm{I}$-labeled subunits were isolated as described above for peptide mapping and cluted from gel slices with 100 $\mu \mathrm{l}$ of $50 \mathrm{mM} \mathrm{NaPO}_{4}, \mathrm{pH} 7.4$, containing $1 \mathrm{~mm}$ EDTA, $0.1 \% \mathrm{SDS}$, and $1 \%$ 2-mercaptoethanol. AChR subunits were digested with glycopeptidase $\mathrm{F}(0.5 \mathrm{unit})$ for $18 \mathrm{hr}$ at $37^{\circ} \mathrm{C}$ in a final volume of $25 \mu \mathrm{l}$. Reactions were stopped by adding $25 \mu$ lof SDS sample buffer ( $2 \times$ concentration) and heating at $100^{\circ} \mathrm{C}$ for $2 \mathrm{~min}$. Control reactions were carried out in the absence of enzyme at either $37^{\circ} \mathrm{C}$ or $4^{\circ} \mathrm{C}$ for $18 \mathrm{hr}$. Proteins were resolved by SDS-PAGE autoradiography as described above.

Immunoblots. Immunoblot analysis was carried out on material isolated with one round of affinity purification as described above except that 500 ganglia were used for each preparation, and the DEAE-cellulose and radioiodination steps were omitted. Electrophoretic transfer of proteins from SDS gels to nitrocellulose paper (Schleicher and Schuell) was carried out as previously described (Towbin et al., 1979). The blots were blocked with $2 \%$ (wt/vol) nonfat dry milk in PBS ( $100 \mathrm{~mm} \mathrm{NaCl}, 0.05 \%$ sodium azide, and $10 \mathrm{~mm} \mathrm{NaPO}$, $\mathrm{pH} 7.4$ ), incubated with $\mathrm{mAbs}$ either for $1 \mathrm{hr}$ at room temperature (mAbs 267 and 268) or overnight (mAbs 35,210 and 270 ) at $4^{\circ} \mathrm{C}$ in PBS and nonfat dry milk containing $0.02 \%$ Tween 20, rinsed in PBS with $0.02 \%$ Tween 20 , incubated with 0.25 $\mathrm{nM}^{125}$ I-goat anti-rat IgG $(1600 \mathrm{cpm} / \mathrm{fmol})$ to detect bound $\mathrm{mAbs}$, rinsed again, and processed for autoradiography as described above for SDSPAGE.

Immunoprecipitation. Immunoprecipitation of isolated AChR subunits was carried out with an antiserum raised against a fusion protein containing a putative cytoplasmic region of the predicted $\alpha 3$ gene product. The $\alpha 3$ fragment of the fusion protein contained 127 amino acids extending from position 315 to position 441 as numbered by Nef et al. (1988) and represented almost exclusively the cytoplasmic loop between putative transmembrane domains 3 and 4 . Prcparation of the fusion protein, generation of the rabbit immune serum, and characterization of the antibody specificity have been described (Schoepfer et al., 1989).

${ }^{125}$ l-labeled AChR subunits were isolated by SDS-PAGE as described above except that elution of subunits from gel slices was carried out in $5 \mathrm{mM} \mathrm{NaPO}_{4}, \mathrm{pH} 7.4$, containing $75 \mathrm{~mm} \mathrm{NaCl}$ and $0.5 \%$ Triton $\mathrm{X}-100$. Reactions $(0.1 \mathrm{ml})$ were carried out in the same solution with the indicated dilutions of rabbit antiserum or preimmune serum (1:30-1:3000) for $1.5-2 \mathrm{hr}$ at room temperature. IgG and bound antigen were precipitated by incubation with $2-3 \mathrm{mg} S$. aureus fixed cells (BRL) for $15 \mathrm{~min}$ followed by centrifugation. The precipitate was rinsed once with the same solution, eluted with SDS-sample buffer, and analyzed by SDSPAGE and autoradiography as described above. To quantitate the proportion of labeled subunit immunoprecipitated by the antiserum individual labeled bands were cut from the fixed and dried gels using an autoradiogram as a template. The radioactive content of excised bands was then determined with a gamma counter and compared to that obtained from bands produced by an equivalent amount of purified subunit without immunoprecipitation, i.e., without antibody or Staphylococcus treatment.

Other procedures. mAb 35 was purified and radioiodinated to specitic activities of $2-3 \times 10^{18} \mathrm{cpm} / \mathrm{mol}$ and was used to measure solubilized 
AChRs with the aid of small DEAE-cellulose columns as previously described (Smith et al., 1985). mAb 35-Sepharose was prepared as previously described (Whiting and Lindstrom, 1986).

Primary cultures of ciliary ganglion neurons were prepared from $8 \mathrm{~d}$ chick embryos and maintained as previously described (Nishi and Berg, 1981), except that $60 \mathrm{~mm}$ dishes were used and each contained about 40 ganglion equivalents of neurons. Culture medium consisted of Eagle's minimal essential medium supplemented with $10 \%$ (vol/vol) heat-inactivated horse serum, 50 units $/ \mathrm{ml}$ penicillin, $50 \mu \mathrm{g} / \mathrm{ml}$ streptomycin, and $3 \%(\mathrm{vol} / \mathrm{vol})$ embryonic eye extract. The medium was changed at 2-3 d intervals. Cultures were taken for experiments after 6-7 d.

Materials. White Leghorn embryonated chick eggs were obtained locally and maintained at $39^{\circ} \mathrm{C}$ in a humidified incubator. Culture media components were obtained as previously described (Nishi and Berg, 1981). The rat mAbs $210,267,268$, and 270 and the rabbit anti- $\alpha 3$ fusion protein antiserum were generously provided by Drs. Paul Whiting, Ralf Schoepfer, and Jon Lindstrom (Salk Institute). Glycopeptidase $\mathrm{F}$ and $S$. aureus V8 protease were purchased from Boehringer Mannheim. Other materials were obtained as previously described (Halvorsen and Berg, 1987).

\section{Results}

Purification of ciliary ganglion AChRs

AChRs were purified from ciliary ganglia of 17- to 19-d-old chick embryos by a combination of ion-exchange chromatography on DEAE-cellulose and immunoaffinity absorption on $\mathrm{mAb} 35-$ Sepharose. Following radioiodination of the immobilized AChR-mAb 35-Sepharose complex, the ${ }^{125}$ I-labeled proteins were acid-eluted and visualized by SDS-PAGE autoradiography. Two major labeled proteins were usually observed having $M_{r}$ 's of about 52 and $60 \mathrm{kDa}$. In addition, a variable amount of a third labeled species was observed with an $M_{r}$ of about $49 \mathrm{kDa}$. All 3 components were specifically purified by the immunoaffinity absorption step since they were not obtained if AChRs were eliminated from the original extract by a preabsorption step with mAb 35-Sepharose (Fig. 1A). Preabsorption with IgG-Sepharose had no effect. Specificity was also indicated by the fact that the 3 components were lost if AChR binding to the immunoaffinity resin during receptor purification was prevented by adding an excess of free mAb 35; an equivalent amount of antibody from normal rat serum again had no effect (Fig. 1A).

A different pattern was obtained when 2 rounds of absorption onto $\mathrm{mAb}$ 35-Sepharose were used instead of one, and the DEAE-cellulose step was omitted (Fig. $1 B$ ). In this case, major components of 49 and $60 \mathrm{kDa}$ were observed with little if any $52 \mathrm{kDa}$ species being present. The amount of material absorbing in the second round, however, was very small, suggesting that acid elution in the first round may have partially denatured the receptor. Accordingly, a less disruptive procedure was developed in which $4.5 \mathrm{M} \mathrm{MgCl}_{2}$ was used to elute material from the first round of $\mathrm{mAb} 35-$ Sepharose absorption. After removing the salt, a much larger fraction of the eluted material was able to rebind to mAb 35-Sepharose for the second round of purification. In 2 experiments in which recoveries were quantified, the $\mathrm{MgCl}_{2}$ elution procedure yielded a 10 -fold greater amount of receptor competent to bind ${ }^{125} \mathrm{I}-\mathrm{mAb} 35$ ( $20 \pm 3$ vs $2 \pm 1 \%$ of the starting material for $\mathrm{MgCl}_{2}$ vs acid elution, respectively). Material eluted from the second round in this case contained the 52 and $60 \mathrm{kDa}$ components as major species (Fig. 1B). Usually, the $49 \mathrm{kDa}$ component was also detectable but represented a minor species. In some cases it was undetectable (Fig. $1 B$ ), while in others it was as abundant as the $52 \mathrm{kDa}$ component (for example, see Fig. 1C). The reason for the variation is not understood; it may be caused by variation in the efficiency of

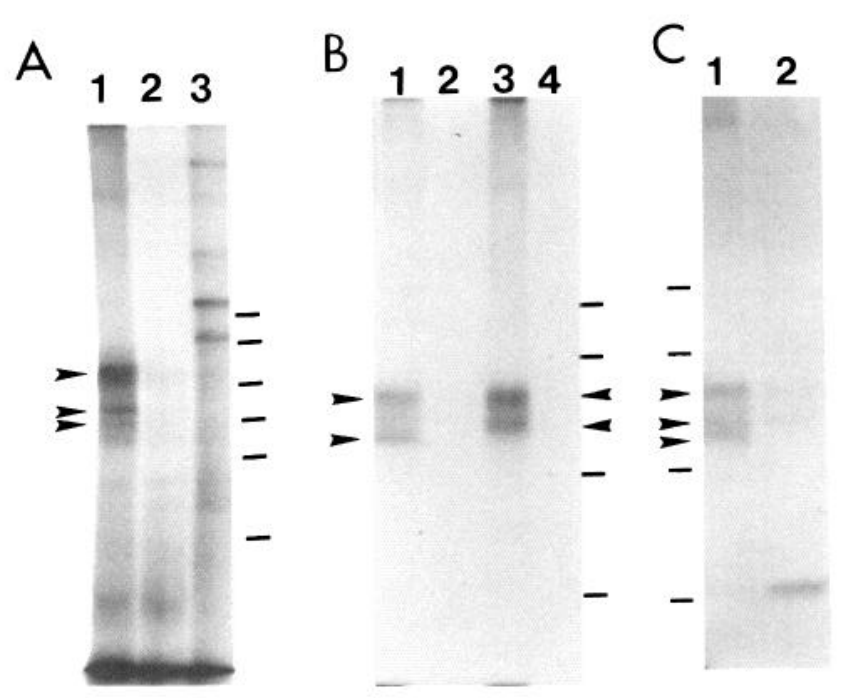

Figure 1. SDS-PAGE of immunoaffinity purified ciliary ganglion AChRs. $A$, AChRs were purified with DEAE-cellulose chromatography and a single round of immunoabsorption on mAb 35-Sepharose, followed by radioiodination, acid-elution, and SDS-PAGE autoradiography. Lane 1, AChRs; radiolabeled proteins eluted from $\mathrm{mAb} 35-\mathrm{Se}$ pharose following absorption of ganglia extract to the resin in the presence of nonimmune rat serum. Lane 2, Nonspecific components; radiolabeled proteins prepared as described for lane 1 except that $2 \mu \mathrm{M} \mathrm{mAb}$ 35 was used to replace nonimmune rat serum, blocking absorption of receptor to the resin. Lane 3, "Nondepleted" components; "receptorfree" material remaining after the mAb 35-Sepharose absorption step used to prepare sample for lane 1 (pass-through) was then absorbed to a second aliquot of $\mathrm{mAb} 35-$ Sepharose, radioiodinated on the resin, and eluted as done for the other samples. Equivalent amounts of radioactivity were applied to each lane. Arrowheads indicate (top to bottom) the 60,52 , and $49 \mathrm{kDa}$ components; lines indicate (top to bottom) the molecular-weight markers transferrin $(85 \mathrm{kDa}), \mathrm{BSA}(68 \mathrm{kDa})$, pyruvate kinase $(57 \mathrm{kDa})$, fumarase $(49 \mathrm{kDa})$, ovalbumin $(43 \mathrm{kDa})$, and carbonic anhydrase $(29 \mathrm{kDa}) . B$, AChRs were purified with 2 rounds of absorption to mAb 35-Sepharose using either acid (lanes $I$ and 2) or $\mathrm{MgCl}_{2}$ (lanes 3 and 4) to elute receptor from the first round of absorption. Binding of receptor to the resin in the second round was carried out in the presence of nonimmune rat serum (1:10 dilution, lanes 1 and $3)$ or $\mathrm{mAb} 35(2 \mu \mathrm{M}$, lanes 2 and 4). Arrowheads (left side) indicate the 60 and $49 \mathrm{kDa}$ components and (right side) the 60 and $52 \mathrm{kDa}$ components (top to bottom). Lines indicate the molecular-weight markers phosphorylase b (97 kDa), BSA, ovalbumin, and carbonic anhydrase. Lanes 1 and 3 received similar amounts of radioactivity ( $c a .2000 \mathrm{cpm}$ ). $C$, AChRs were purified from ciliary ganglion cell cultures as described in $B$ for receptors from ganglia. $\mathrm{MgCl}_{2}$ was used to elute receptor from the first round of immunoaffinity absorption. Lane 1, AChRs; lane 2, nonspecific components as in A. Arrowheads (top to bottom) indicate the 60,52 , and $49 \mathrm{kDa}$ components. Differences in the relative amounts of $49 \mathrm{kDa}$ component for lanes $\mathrm{B} 3$ and $\mathrm{Cl}$ represent the range of variation encountered among preparations; similar results were obtained with AChRs purified both from ganglia and from cell culture.

receptor elution from the immunoaffinity resin. Similar results were obtained with AChRs immunopurified from ciliary ganglion neurons grown in cell culture (Fig. $1 \mathrm{C}$ ), indicating that the 49,52 , and $60 \mathrm{kDa}$ species were all present in ganglionic neurons rather than one or more of the species deriving from AChRs of possible preganglionic origin. In all cases, the components were specifically purified by immunoaffinity absorption with mAb 35-Sepharose by the criteria cited above, namely, that they were not obtained if the extract was first preabsorbed with $\mathrm{mAb} 35$ Sepharose to remove receptor or if receptor binding to the immunoaffinity resin was prevented by including an excess of free $\mathrm{mAb} 35$. The measured sizes for the 49,52 , and $60 \mathrm{kDa}$ species 


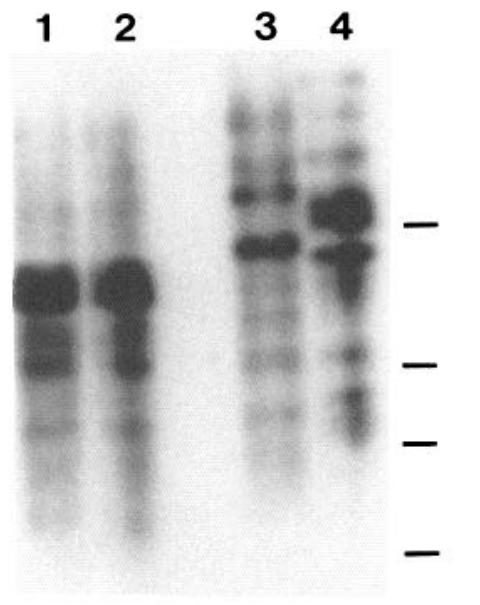

Figure 2. Peptide mapping of ciliary ganglion AChR components on SDS- $15 \%$ polyacrylamide gels. AChRs were immunoaffinity purified with 2 rounds of absorption to $\mathrm{mAb} 35$-Sepharose, using the indicated elution procedure to recover receptor from the first round in each case. The ${ }^{125}$ I-labeled components were separated by SDS-PAGE, eluted from gel slices, subjected to limited proteolysis with Staphylococcus V8 protease, and then examined by SDS-PAGE autoradiography. Lane 1, 60 $\mathrm{kDa}$ component, $\mathrm{MgCl}_{2}$-elution; lane $2,60 \mathrm{kDa}$ component, acid-elution; lane 3, $52 \mathrm{kDa}$ component, $\mathrm{MgCl}_{2}$-elution; lane 4, $49 \mathrm{kDa}$ component, acid-elution. Indicated Bio-Rad prestained molecular-weight standards are $\alpha$-chymotrypsinogen ( $26 \mathrm{kDa}) ; \beta$-lactoglobulin (18 kDa); lysozyme $(14 \mathrm{kDa})$, bovine trypsin inhibitor $(6 \mathrm{kDa})$.

after 2 rounds of immunoaffinity purification were $48,900 \pm$ $200 \mathrm{kDa}$ (11 determinations with $7 \mathrm{AChR}$ preparations), 52,300 $\pm 500 \mathrm{kDa}$ (8 determinations with $5 \mathrm{AChR}$ preparations), and $59,500 \pm 200 \mathrm{kDa}$ (11 determinations with $7 \mathrm{AChR}$ preparations), respectively.

\section{Peptide mapping of isolated components}

Peptide mapping of the isolated components indicated that neither of the smaller species represented degradation products of a larger species in the trio. ${ }^{125} \mathrm{I}$-labeled AChRs were immunopurified with 2 rounds of absorption to mAb 35-Sepharose using either acid elution after the first round to obtain predominantly the 49 and $60 \mathrm{kDa}$ species, or $\mathrm{MgCl}_{2}$ elution after the first round to obtain predominantly the 52 and $60 \mathrm{kDa}$ species. The components were then separated by SDS-PAGE, eluted from gel slices, and subjected to limited proteolysis by Staphylococcus V8 protease. The ${ }^{125} \mathrm{I}$-peptide fragments resulting from each component were fractionated and visualized by SDS-PAGE autoradiography. The enzyme treatment revealed no differences in the peptide pattern produced from the $60 \mathrm{kDa}$ species isolated by the 2 procedures (Fig. 2). Unique peptide patterns were obtained for the 49 and $52 \mathrm{kDa}$ species, indicating that each represented a distinct component and that neither derived from the $60 \mathrm{kDa}$ species (Fig. 2).

\section{Deglycosylation of the isolated components}

Several lines of evidence indicate that ciliary ganglion AChRs are glycoproteins. The ACh sensitivity of ciliary ganglion neurons in culture is inhibited by exposure to concanavalin A (Messing et al., 1984). Detergent-solubilized AChRs bind to the lectin concanavalin A (Smith et al., 1985). Tunicamycin, which blocks asparagine-linked glycosylation, prevents the appearance of newly
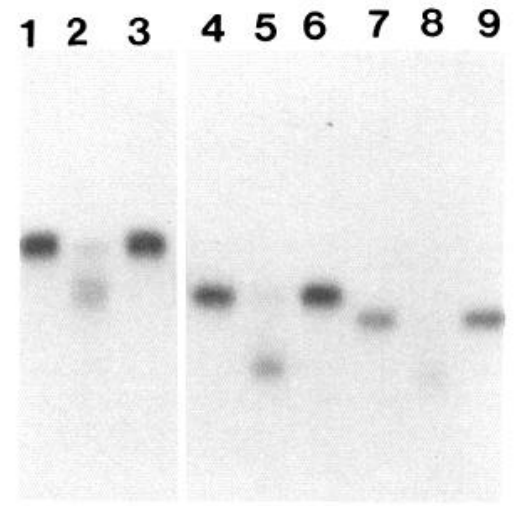

Figure 3. Digestion of ciliary ganglion AChR components with glycopeptidase $\mathrm{F}$. AChRs were immunoaffinity-purified with 2 rounds of absorption to $\mathrm{mAb} 35$-Sepharose, using $\mathrm{MgCl}_{2}$ to elute receptor from the first round of absorption. SDS-PAGE autoradiography confirmed that all 3 types of components were present. The ${ }^{125}$ I-labeled species were eluted from gel slices, digested with glycopeptidase $\mathrm{F}$, and examined by SDS-PAGE autoradiography. Lanes $1-3,60 \mathrm{kD}$ component; lanes 4-6, $52 \mathrm{kDa}$ component; lanes 7-9, $49 \mathrm{kDa}$ component. Lanes 1, 4 , and $7,37^{\circ} \mathrm{C}$ incubation, no enzyme; lanes 2,5 , and $8,37^{\circ} \mathrm{C}$ incubation with 0.5 unit glycopeptidase $\mathrm{F}$ per sample; lanes 3,6 , and $9,4^{\circ} \mathrm{C}$ incubation, no enzyme.

synthẹsized AChRs on the neuron surface (Stollberg and Berg, 1987). To determine whether any of the 3 isolated components is glycosylated, AChRs were immunopurified with 2 rounds of absorption to $\mathrm{mAb}$ 35-Sepharose, using either acid or $\mathrm{MgCl}_{2}$ to elute from the first round. The components were then eluted separately from gel slices, treated with glycopeptidase F to remove carbohydrate moieties, and reexamined by SDS-PAGE autoradiography. Glycopeptidase F cleaves N-linked carbohydrates between asparagine and the carbohydrate chain. Treatment of the components for $18 \mathrm{hr}$ with the enzyme produced a substantial increase in their mobilities, indicating that each had a significant carbohydrate content (Fig. 3). $M_{r}$ 's of $43 \pm 1(n=$ $3), 45 \pm 1(n=5)$, and $53 \pm 1(n=6) \mathrm{kDa}$ (mean $\pm \mathrm{SE})$ were obtained for the 49,52 , and $60 \mathrm{kDa}$ components, respectively, after the digestion. The results indicate that all 3 are glycoproteins and have unique polypeptide sizes after removing $\mathrm{N}$-linked carbohydrates.

\section{Immunoprecipitation of the $60 \mathrm{kDa}$ Component}

The $60 \mathrm{kDa}$ species was a strong candidate for an $\alpha$ subunit in the receptor since previous studies indicated that a subunit of similar size was covalently labeled when the receptor was reacted with a photoaffinity derivative of a neurotoxin that blocks receptor function (Halvorsen and Berg, 1987). Of the AChR $\alpha$ genes, $\alpha 3$ was most likely to encode the $60 \mathrm{kDa}$ species since $\alpha 3$ mRNA but not $\alpha 2$ or $\alpha 4$ mRNA is abundant in the ganglion (Boyd et al., 1988). To test this, AChR components were separated by SDS-PAGE, eluted, and reacted with an antiserum raised against a fusion protein containing a putative cytoplasmic region of the $\alpha 3$ gene product (Schoepfer et al., 1989). The antiserum preferentially and specifically immunoprecipitated the $60 \mathrm{kDa}$ species (Fig. 4A). Small amounts of labeled material in the 49 and $52 \mathrm{kDa}$ samples were also immunoprecipitated by the antiserum either because of a low cross-reactivity of the serum with the 2 smaller components or because of degraded $60 \mathrm{kDa}$ species migrating in the $50-60 \mathrm{kDa}$ region of the gel. That some degradation of the $60 \mathrm{kDa}$ species occurs during the 
experiment was demonstrated by resubmitting purified $60 \mathrm{kDa}$ component to SDS-PAGE and finding that some of the material migrated in the $50-60 \mathrm{kDa}$ region below that of the major constituent at $60 \mathrm{kDa}$ (data not shown).

Immunoprecipitation of the $60 \mathrm{kDa}$ species was characterized further by determining the titer of the antiserum for the component. An antiserum dilution of 1:300 precipitated about $80 \%$ of the available component and represented near-maximal precipitation under the conditions used (Fig. 4B). This is in good agreement with previous results obtained with intact receptor where an antiserum dilution of 1:300 precipitated $80 \%$ of the solubilized ciliary ganglion AChRs detected with mAb 35 (Schoepfer et al., 1989).

\section{AChR immunoblots}

Immunoblots were used to examine the cross-reactivity of ciliary ganglion AChR components with mAbs previously shown to recognize components associated with brain AChRs. Five mAbs were tested here. All had previously been shown to recognize components of about $49 \mathrm{kDa}$ in preparations of AChRs immunopurified from chicken brain (Whiting et al., 1987b). Four of the mAbs (mAbs 35, 210, 268, and 267) cross-reacted with the ganglionic $49 \mathrm{kDa}$ component (Fig. 5). The fifth $\mathrm{mAb}$ ( $\mathrm{mAb} 270)$ failed to recognize the ganglionic species. None of the mAbs cross-reacted with either the 52 or $60 \mathrm{kDa}$ ganglionic components, even though one of the mAbs (mAb 267) recognizes both a 49 and a $59 \mathrm{kDa}$ species associated with brain AChRs (Whiting et al., 1987b). Higher-molecular-weight bands visible on the immunoblots were judged to be nonspecific since they were present in equivalent amounts for AChR and "receptor free" samples (Fig. 5).

\section{Discussion}

The 49,52 , and $60 \mathrm{kDa}$ components all appear to be distinct species which can be specifically immunoaffinity-purified with a $\mathrm{mAb}$ that recognizes ciliary ganglion $\mathrm{AChRs}$. Each component produces a distinctive peptide map, confirming that it represents a unique species rather than the smaller ones being degradation products of larger ones in the trio. Each component is a glycoprotein, suggesting that it has an extracellular domain. Each retains a unique size after digestion with glycopeptidase F, demonstrating that the differences observed among the components are not the consequence of different $\mathrm{N}$-linked glycosylation patterns.

The $60 \mathrm{kDa}$ component is similar in size to an $\mathrm{AChR}$ subunit previously identified by affinity labeling with a neurotoxin that blocked receptor function (Halvorsen and Berg, 1987). Additional evidence that the $60 \mathrm{kDa}$ component represents an AChR subunit comes from the finding that it can be selectively immunoprecipitated with an antiserum raised against an $\alpha 3$ fusion protein. The fusion protein was constructed to include a putative cytoplasmic domain of the $\alpha 3$ gene product that had little homology with other AChR genes (Schoepfer et al., 1989). Previous studies on the specificity of the antiserum demonstrated that it immunoprecipitated solubilized ciliary ganglion AChRs but not solubilized brain AChRs, thought to lack the $\alpha 3$ subunit or solubilized ciliary ganglion $\alpha$-bungarotoxin binding components (Schoepfer et al., 1989). Only a small amount of crossreactivity with other $A C h R$ subunits would be expected from the fact that the fusion protein used to generate the antiserum included a short region of $\alpha 3$ (corresponding to 7 amino acids) that was homologous to other AChR genes (Schoepfer et al.,
A

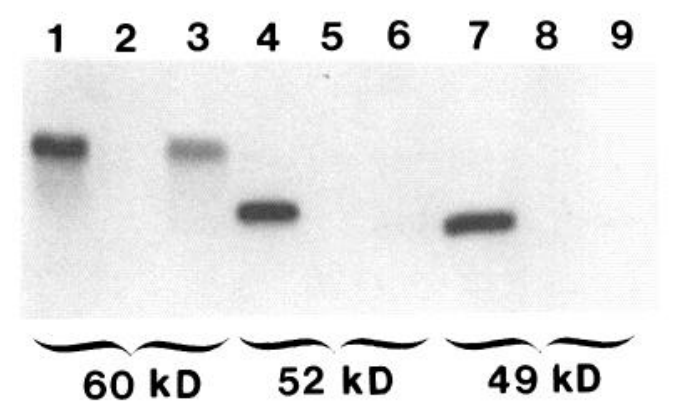

B

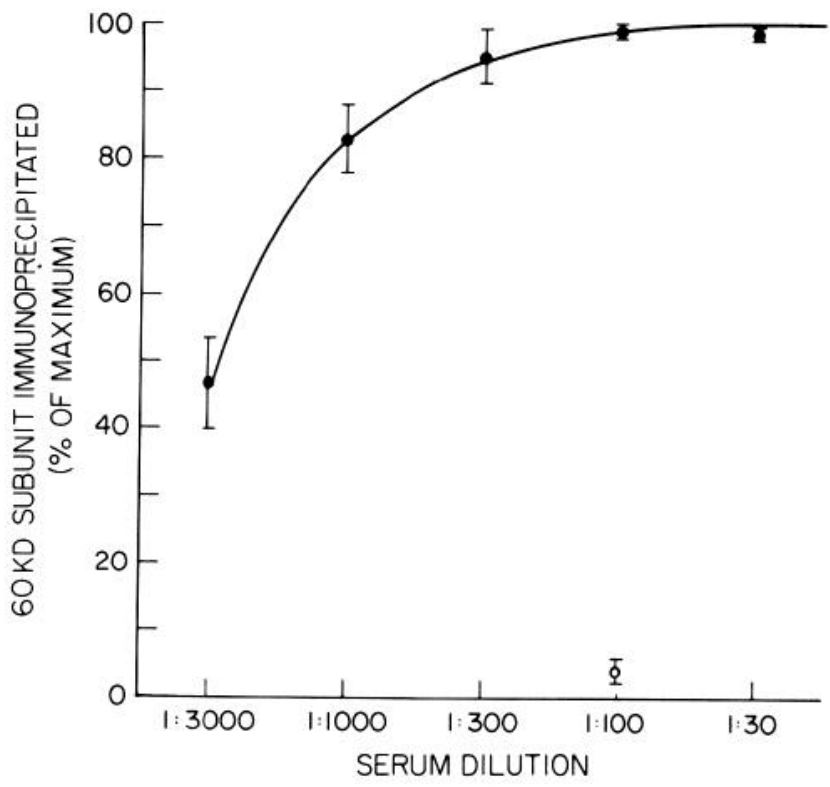

Figure 4. Immunoprecipitation of isolated ciliary ganglion AChR 60 $\mathrm{kDa}$ component using an antiserum raised against an $\alpha 3$ fusion protein. AChR components were isolated by elution from gel slices as described in Figure 3 and incubated with serum. IgG and bound antigen were collected by centrifugation with fixed Staphylococcus cells and analyzed by SDS-PAGE. A, Autoradiogram of gel. Lanes 1, 4, and 7, purified components before reacting with serum; lanes 2,5 , and 8 , immunoprecipitate collected after reacting components with 1:100 dilution of preimmune serum; Lanes 3, 6, and 9, immunoprecipitate collected after reacting components with 1:100 dilution of anti- $\alpha 3$ fusion protein antiserum. Reactions contained about $1100 \mathrm{cpm}$ of radiolabeled component. $B$, Titration of anti- $\alpha 3$ fusion protein antiserum against isolated $60 \mathrm{kDa}$ component. Aliquots of isolated ${ }^{125}$ I-labeled $60 \mathrm{kDa}$ component were incubated with the indicated dilutions of antiserum (filled circles) or a 1:100 dilution of pre-immune serum (open circle) for 2 hours at room temperature, and the immunoprecipitates were collected and subjected to SDS-PAGE as described above. The $60 \mathrm{kDa}$ region of the gel was excised and examined for radioactivity with a gamma counter. Data represent the mean \pm SEM of 3 experiments using separate AChR preparations, and are presented as a percent of the maximum proportion of $60 \mathrm{kDa}$ component immunoprecipitated where the maximum for the 3 experiments was $79 \pm 9 \%$ of the radiolabeled component present. 


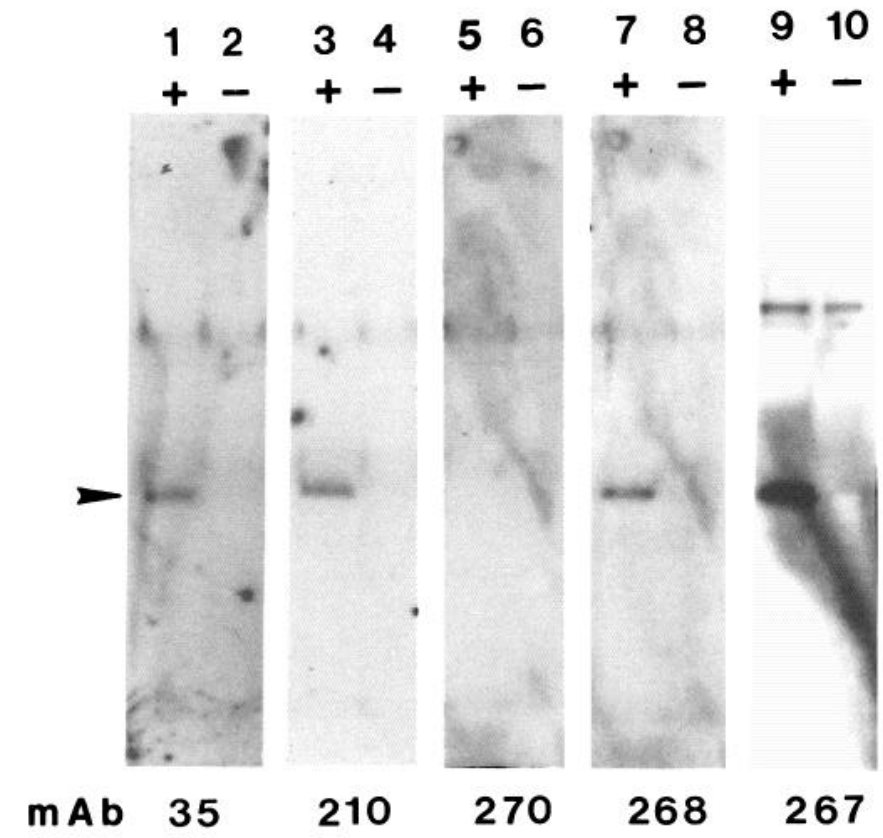

Figure 5. Immunoblots of ciliary ganglion $\mathrm{AChRs}$ probed with anti$\mathrm{AChR}$ monoclonal antibodies. Purified AChR and corresponding "receptor-free" control samples (see Materials and Methods) were separated by SDS-PAGE and transferred to nitrocellulose paper. Lanes 1 3, 5, 7, and 9, AChR sample (+); lanes 2, 4, 6, 8, and 10, "AChRdepleted" sample (-). Lanes were probed with the indicated mAbs (35, $210,270,268$, and 267). Lanes 1-8 are from a single blot, while lanes 9 and 10 are from a separate blot. Lanes 7 and 8 represent lanes 5 and 6 after rinsing $30 \mathrm{~min}$ in $10 \mathrm{mM} \mathrm{NaPO}_{4}, \mathrm{pH} \mathrm{7.4}$, containing $0.5 \mathrm{M} \mathrm{NaCl}$ and $0.5 \%$ Triton $\mathrm{X}-100$, and then reprobing with $\mathrm{mAb} 268$. mAbs 35 and 210 were used at $2 \mu \mathrm{M} ; \mathrm{mAbs} 270,268$, and 267 were used at 1:50 dilutions from previously described stocks (Whiting et al., 1987b). Bound antibodies were visualized with ${ }^{125} \mathrm{I}$-goat anti-rat $\mathrm{IgG}$, followed by autoradiography. Arrowhead, position of $49 \mathrm{kDa}$ component.

1989). Nonetheless, we cannot exclude the possibility that some or all of the immunoprecipitated material actually represents the product of a closely related gene, e.g., some as yet unidentified AChR $\alpha$ subunit. A substantial amount of $\alpha 3$ subunit would be expected to be present, however, given the amount of $\alpha 3$ mRNA in the neurons (Boyd et al., 1988). Failure to precipitate more than $80 \%$ of the isolated $60 \mathrm{kDa}$ component with the anti- $\alpha 3$ antiserum here probably reflects both the limitations of the reaction conditions used and the presence of some contaminating material in the $60 \mathrm{kDa}$ sample. The small amount of radiolabeled material immunoprecipitated from the 49 and $52 \mathrm{kDa}$ samples by the antiserum is likely to be degraded 60 kDa subunit.

The ganglionic $49 \mathrm{kDa}$ component is the same size as a component previously found in AChR preparations obtained from chicken, rat, and bovine brain (Whiting et al., 1987b; Whiting and Lindstrom, 1988). mAbs 35, 210, 267, 268, and 270 have all been shown to react with components of about $49 \mathrm{kDa}$ on immunoblots of chick brain AChRs (Whiting et al., 1987b; Schoepfer et al., 1989), and amino acid sequence analysis of the material reveals some $\beta 2$ gene product (Schoepfer et al., 1988). Recent evidence suggests that of the $5 \mathrm{mAbs}$, however, $\mathrm{mAb}$ 270 may be the only one to react with a $\beta 2$ gene product ( $\mathrm{J}$. Lindstrom, personal communication). If so, it would imply that the other $4 \mathrm{mAbs}$ may be detecting a separate gene product at
$49 \mathrm{kDa}$ in preparations of brain AChRs. The ganglionic $49 \mathrm{kDa}$ component on immunoblots reacts with the same $4 \mathrm{mAbs}$ (mAbs $35,210,267$, and 268) as the brain component and does not react detectably with $\mathrm{mAb} 270$ under these conditions.

The $52 \mathrm{kDa}$ component has not previously been identified in preparations of neuronal AChRs. The evidence that it is associated with ciliary ganglion AChRs comes from the demonstration that it specifically copurifies with receptor through 2 rounds of immunoaffinity absorption using mAb 35, which has previously been shown by several criteria to bind to ganglionic AChRs (Jacob et al., 1984; Smith et al., 1985, 1986; Halvorsen and Berg, 1987).

Neither the 49 or $52 \mathrm{kDa}$ component is likely to be encoded by the $\alpha 3$ gene since neither is immunoprecipitated by the anti$\alpha 3$ antiserum, and peptide mapping confirms that neither is related to the $60 \mathrm{kDa}$ subunit which does react with the antiserum. Two candidates for other genes encoding AChR subunits in the ganglion include the $\beta 2$ gene since it is expressed at low levels in chick ciliary ganglion neurons (Boyd et al., 1988), and a chicken homolog of the recently described rat neuronal AChR $\beta 4$ gene. The $\beta 4$ gene is expressed in the rat pheochromocytoma cell line PC12 (Duvoisin et al., 1989), and a possible variant of it has been isolated from a cDNA library prepared from the rat superior cervical ganglion (Isenberg and Meyer, 1989).

It is premature to conclude, however, that the 49 and $52 \mathrm{kDa}$ components are integral AChR subunits. They may be peripheral membrane proteins associated with the receptor, as proposed for the $93 \mathrm{kDa}$ protein of glycine receptors (Langosch et al., 1988) and the $43 \mathrm{kDa}$ protein associated with muscle and electric organ AChRs (Carr et al., 1987; Frail et al., 1988). In the case of the $49 \mathrm{kDa}$ component, it is even possible that it purifies independently from AChRs by virtue of an ability to bind directly to mAb 35-Sepharose. Supporting the speculation that the 49 and $52 \mathrm{kDa}$ components represent AChR subunits are the observations that both are glycoproteins and both specifically purify with $\mathrm{mAb} 35-$ Sepharose in Triton X-100 detergent. Intracellular peripheral membrane proteins such as the AChR-associated $43 \mathrm{kDa}$ component are usually not glycosylated and do not remain associated with the receptor under these conditions; the available evidence suggests that the antibody is specific for AChRs as cited above. It should also be noted that additional AChR subunits may exist in the chick ciliary ganglion but went undetected in the present study because of inadequate amounts, selective proteolysis, or association with AChRs not immunopurified with mAb 35 .

If the 3 components all represent $A C h R$ subunits, they present the possibility that the ganglion contains a single type of AChR with at least 3 types of subunits. Such a proposal would diverge from previous models for brain AChRs specifying only 2 types of subunits per receptor subtype (Whiting and Lindstrom, 1986, 1987a, 1988; Whiting et al., 1987b). In principle, 2 types of subunits can provide a functional AChR since 2 neuronal AChR gene products are sufficient for ACh responses from Xenopus oocytes (Boulter et al., 1987; Ballivet et al., 1988; Wada et al., 1988; Duvoisin et al., 1989). The issue of subunit complexity remains an open one, however, because abnormal subunit combinations can produce functional responses in Xenopus oocytes (Mishina et al., 1984; Boulter et al., 1987; Pritchett et al., 1989). Subunits can also be overlooked during SDS-PAGE because of selective proteolysis (Lindstrom et al., 1980) or comigration of multiple species. On the other hand, one difficulty with the hypothesis that all 3 ganglionic components are part of the same AChR comes from the observation that only 2 components were 
obtained (49 and $60 \mathrm{kDa}$ species) in the purification scheme where mild acid was used to elute receptor between the 2 rounds of immunoaffinity absorption. Possibly the $52 \mathrm{kDa}$ component is preferentially removed from ganglionic AChRs by mild acid treatment, but no precedent exists for this in studies of other AChRs.

A second possible configuration is that the 3 identified components make up 2 distinct receptor subtypes, one having 49 and $60 \mathrm{kDa}$ subunits and the other having 52 and $60 \mathrm{kDa}$ subunits. The $52 / 60 \mathrm{kDa}$ receptor subtype would appear to be the more prevalent of the 2 receptor species in the ganglion since more $52 \mathrm{kDa}$ component is usually detectable at early purification stages than $49 \mathrm{kDa}$ component. The fact that only the $49 \mathrm{kDa}$ component cross-reacts detectably with mAb 35 on receptor immunoblots does not imply that all receptor species must have the $49 \mathrm{kDa}$ component to be immunoaffinity-purified with $\mathrm{mAb} 35$. The present studies show that the mAb 35 binding epitope on ganglionic AChRs is at least partially sensitive to denaturing conditions as it is on brain AChRs (Whiting and Lindstrom, 1986). Accordingly, in the native configuration the antibody may, for example, recognize epitopes on either the 52 or $60 \mathrm{kDa}$ species as well, thereby permitting purification of both receptor subtypes. A greater lability of the epitope in these latter cases following receptor denaturation would not only account for the failure to detect 52 or $60 \mathrm{kDa}$ species with $\mathrm{mAb}$ 35 on immunoblots but would also be consistent with the proposed preferential loss of the $52 / 60 \mathrm{kDa}$ receptor species during harsh purification procedures.

If $2 \mathrm{AChR}$ subtypes are present in the ciliary ganglion, they may be expressed (1) by the same neurons, (2) by different neurons (e.g., choroid vs ciliary cells), or (3) by the same neurons but with different subcellular locations (e.g., synaptic vs extrasynaptic sites or surface vs intracellular locations). Two classes of AChR single-channel events ( 25 and $40 \mathrm{pS}$ ) have been detected for ciliary ganglion neurons (Margiotta and Gurantz, 1989), perhaps reflecting 2 distinct receptor types. Another kind of AChR heterogeneity in the ganglion concerns the functional state of the receptor. Ciliary ganglion AChRs may convert between "silent" and "functionally available" states, depending in part on a cAMP-dependent process (Margiotta et al., 1987a, b; Margiotta and Gurantz, 1989). The role of subunit composition in the conversion has yet to be investigated, but studies with protein synthesis inhibitors exclude the possibility that de novo synthesis of a particular subunit species is required for the conversion.

The peptide mapping studies indicate that if the identified components make up 2 distinct types of receptors, both are likely to contain the same type of $60 \mathrm{kDa}$ subunit. This conclusion is further supported by the finding that nearly all of the ciliary ganglion AChRs recognized by $\mathrm{mAb} 35$ can also bc immunoprecipitated by the antiserum to the $\alpha 3$ fusion protein (Schoepfer et al., 1989). During sucrose gradient sedimentation, most of the ganglionic receptor migrates at $10 \mathrm{~S}$ (Smith et al., 1985), suggesting a molecular size of $250-300 \mathrm{kDa}$. The size could accommodate 5 copies of subunits in the $49-60 \mathrm{kDa}$ range in any of several combinations, retaining the basic pentameric motif of subunit organization seen in muscle and electric organ AChRs.

\section{References}

Ballivet M, Nef P, Couturier S, Rungger D, Bader CR, Bertrand D, Cooper E (1988) Electrophysiology of a chick neuronal acetylcholine receptor expressed in Xenopus oocytes after cDNA injection. Neuron $1: 847-852$.

Boulter J, Evans K, Goldman D, Martin G, Treco D, Heinemann S, Patrick J (1986) Isolation of a cDNA clone coding for a possible neural nicotinic acetylcholine receptor $\alpha$-subunit. Nature 319:368374.

Boulter J, Connolly J, Deneris E, Goldman D, Heinemann S, Patrick J (1987) Functional expression of two neuronal nicotinic acetylcholine receptors from cDNA clones identifies a gene family. Proc Natl Acad Sci USA 84:7763-7767.

Boyd RT, Jacob MH, Couturier S, Ballivet M, Berg DK (1988) Expression and regulation of neuronal acetylcholine receptor mRNA in chick ciliary ganglia. Neuron 1:495-502.

Carr C, McCourt D, Cohen JB (1987) The 43-kilodalton protein of Torpedo nicotinic postsynaptic membranes: purification and determination of primary structure. Biochemistry 26:7090-7102.

Cleveland DW, Fischer SG, Kirschner MW, Laemmli UK (1977) Peptide mapping by limited proteolysis in sodium dodecyl sulfate and analysis by gel electrophoresis. J Biol Chem 252:1102-1106.

Deneris ES, Connolly J, Boulter J, Wada E, Wada K, Swanson LW, Patrick J, Heinemann S (1988) Primary structure and expression of $\beta 2$ : a novel subunit of neuronal nicotinic acetylcholine receptors. Neuron 1:45-54.

Deneris ES, Boulter J, Swanson LW, Patrick J, Heinemann S (1989) B3: a new member of nicotinic acetylcholine receptor gene family is expressed in brain. J Biol Chem 264:6268-6272.

Duvoisin RM, Deneris ES, Patrick J, Heinemann S (1989) The functional diversity of the neuronal nicotinic acetylcholine receptors is increased by a novel subunit: $\beta 4$. Neuron $3: 487-496$.

Frail DE, McLaughlin LL, Mudd J, Merlie JP (1988) Identification of the mouse muscle 43,000-dalton acetylcholine receptor-associated protein (RAPsyn) by cDNA cloning. J Biol Chem 263:1 5602-15607.

Goldman D, Deneris E, Luyten W, Kochhar A, Patrick J, Hcincmann S (1987) Members of a nicotinic acetylcholine receptor gene family are expressed in different regions of the mammalian central nervous system. Cell 48:965-973.

Halvorsen SW, Berg DK (1986) Identification of a nicotinic acetylcholine receptor on neurons using an $\alpha$-neurotoxin that blocks receptor function. J Neurosci 6:3405-3412.

Halvorsen SE, Berg DK (1987) Affinity labeling of neuronal acetylcholine receptor subunits with an $\alpha$-neurotoxin that blocks receptor function. J Neurosci 7:2547-2555.

Isenberg KE, Meyer GE (1989) Cloning of a putative neuronal nicotinic acetylcholine receptor subunit. J Neurochem 52:988-991.

Jacob MH, Berg DK, Lindstrom JM (1984) Shared antigenic determinant between the Electrophorus acetylcholine receptor and a synaptic component on chicken ciliary ganglion ncurons. Proc Natl Acad Sci USA 81:3223-3227.

Laemmli UK (1970) Cleavage of structural proteins during the assembly of the head of bacteriophage T4. Nature 277:680-685.

Langosch D, Thomas L, Betz H (1988) Conserved quaternary structure of ligand-gated ion channels: the postsynaptic glycine receptor is a pentamer. Proc Natl Acad Sci USA 85:7394-7398.

Lindstrom J, Gullick W, Conti-Tronconi B, Ellisman M (1980) Proteolytic nicking of the acetylcholine receptor. Biochemistry 19:47914795.

Mains RE, Eipper BA (1976) Biosynthesis of adrenocorticotropic hormone in mouse pituitary tumor cells. J Biol Chem 251:4115 4120 .

Margiotta JF, Gurantz D (1989) Changes in the number, function, and regulation of nicotinic acetylcholine receptors during neuronal development. Dev Biol 135:326-339.

Margiotta JF, Berg DK, Dionne VE (1987a) Properties and regulation of functional acetylcholine receptors on chick ciliary ganglion neurons. J Neurosci 7:3612-3622.

Margiotta JF, Berg DK, Dionne VE (1987b) Cyclic AMP regulates the proportion of functional acetylcholine receptors on chicken ciliary ganglion neurons. Proc Natl Acad Sci USA 84:8155-8159.

Messing A, Bizzini B, Gonatas NK (1984) Concanavalin A inhibits nicotinic acetylcholine receptor function in cultured chick ciliary ganglion neurons. Brain Res 303:241-249.

Mishina M, Kurosaki T, Tobimatsu T, Morimoto Y, Noda M, Yamamoto $T$, Terao $M$, Lindstrom J, Takahashi $T$, Kuno $M$, Numa $S$ (1984) Expression of functional acetylcholine receptor from cloned cDNAs. Nature 307:604-608.

Nef P, Oneyser C, Alliod C, Couturier S, Ballivet M (1988) Genes expressed in the brain define three distinct neuronal nicotinic acetylcholine receptors. EMBO J 7:595-601. 
Nishi R, Berg DK (1981) Two components from eye tissue that differentially stimulate growth and development of ciliary ganglion neurons in culture. $J$ Neurosci 1:505-513.

Papke RL, Boulter J, Patrick J, Heinemann S (1989) Single-channel currents of rat neuronal nicotinic acetylcholine receptors expressed in Xenopus oocytes. Ncuron 3:589-596.

Pritchett DB, Sontheimer H, Shivers BD, Ymer S, Kettenmann H, Schofield PR, Seeburg PH (1989) Importance of a novel GABA receptor subunit for benzodiazepine pharmacology. Nature 338:582585.

Schoepfer R, Whiting P, Esch F, Blacher R, Shimasaki S, Lindstrom J (1988) cDNA clones coding for the structural subunit of a chicken brain nicotinic acetylcholine receptor. Neuron 1:241-248.

Schoepfer R, Halvorsen SW, Conroy WG, Whiting P, Lindstrom J (1989) Antisera against an acetylcholine receptor $\alpha 3$ fusion protein bind to ganglionic but not to brain acetylcholine receptors. FEBS Lett 257:393-399

Schuetze SM, Role LW (1987) Developmental regulation of nicotinic acetylcholine receptors. Ann Rev Neurosci 10:403-457.

Smith MA, Stollberg J, Lindstrom JM, Berg DK (1985) Characterization of a component in chick ciliary ganglia that crossreacts with monoclonal antibodies to muscle and electric organ acetylcholine receptor. J Neurosci 5:2726-2731.

Smith MA, Margiotta JF, Franco A, Jr, Lindstrom JM, Berg DK (1986) Cholinergic modulation of an acetylcholine receptor-like antigen on the surface of chick ciliary ganglion neurons in cell culture. J Neurosci 6:946-953.

Stollberg J, Berg DK (1987) Neuronal acetylcholine receptors: fate of surface and internal pools in cell culture. J Neurosci 7:1809-1815.

Towbin H, Staehelin T, Gordon J (1979) Electrophoretic transfer of proteins from polyacrylamide gels to nitrocellulose sheets: procedure and some applications. Proc Natl Acad Sci USA 76:4350-4354.

Wada K, Ballivet M, Boulter J, Connolly J, Wada E, Deneris ES, Swanson LW, Hcincmann S, Patrick J (1988) Functional expression of a new pharmacological subtype of brain nicotinic acetylcholine receptor. Science 240:330-334.

Whiting P, Lindstrom J (1986) Purification and characterization of a nicotinic acetylcholine receptor from chick brain. Biochemistry 25 : 2082-2093.

Whiting P, Lindstrom J (1987a) Purification and characterization of a nicotinic acetylcholine receptor from rat brain. Proc Natl Acad Sci USA 84:595-599.

Whiting P, Lindstrom J (1987b) Affinity labeling of neuronal acetylcholine receptors localizes acetylcholine-binding sites to their $\beta$-subunits. FEBS Lett 213:55-60.

Whiting P, Lindstrom J (1988) Characterization of bovine and human neuronal nicotinic acetylcholine receptors using monoclonal antibodies. J Neurosci 8:3395-3404.

Whiting P, Esch F, Shimasaki S, Lindstrom J (1987a) Neuronal nicotinic acetylcholine receptor $\beta$-subunit is coded for by the cDNA clone $\alpha_{4}$. FEBS Lett 219:459-463.

Whiting PJ, Liu R, Morley BJ, Lindstrom JM (1987b) Structurally different neuronal nicotonic acetylcholine receptor subtypes purified and characterized using monoclonal antibodies. J Neurosci 7:40054016. 